\title{
Experimental Investigation of Porous Concrete for Concrete Pavement
}

\author{
Harshith $^{1}$, Shashivendra Dulawat ${ }^{2}$, Dr. Esar Ahmad ${ }^{3}$ \\ ${ }^{1}$ Student, M.Tech, Mewar University, Rajasthan, India \\ ${ }^{2}$ Assistant Professor, Dept. of Civil Engineering, Mewar University, Rajasthan, India \\ ${ }^{3}$ Professor\&Hod Dept. of Civil Engineering, Mewar University, Rajasthan, India
}

\begin{abstract}
Porous Concrete may be an extraordinary strong structure utilized in the progression field, another name of it is dry concrete other than broken concrete, no fines concrete and porous concrete. Water is a noteworthy constituent. Penetrable concrete is an uncommon kind of strong, which includes concrete, coarse aggregates, water and at whatever point required, admixtures and distinctive cementations materials. As there are no fine aggregates used in the strong cross section, the void substance is more which allows the water to travel through its body. Permeable concrete fuses solid, water and if vital, course masses, admixtures and unmistakable cementations constituents. There is bundle of exploration work is going in the field of porous concrete. The quality traits and structure of porous concrete is less when appeared differently in relation to the standard concrete on account of its porosity and voids. Thus, the utilization of porous concrete is compelled in spite of the way that it has some portion of good conditions. If the compressive quality and flexural nature of porous concrete is extended, by then it might be used for logically number of uses. For the present, the utilization of penetrable concrete is generally limited to light traffic lanes so to speak. If the properties are improved, by then it can similarly be used for medium and significant traffic inflexible pavements besides. Close by that, the penetrable concrete takes out surface overflow of storm water, empowers the ground water restore and makes the fruitful use of open land. This guideline purpose of our endeavor deals with the connection of flexural quality, compressive quality and porosity of concrete between porous concrete with no fine masses with replacement of cement and structure of penetrable concrete. However, it will in general be seen that with increase in quality, the permeability of penetrable strong will be diminished.
\end{abstract}

Keywords: Porous Concrete, Compressive Strength, Flexural Strength, Porosity of Cement Concrete Pavement.

\section{INTRODUCTION}

Permeable solid which is otherwise called the no-fines, Porous, hole reviewed, and penetrable cement and Enhance porosity concrete are a dependable tempest water the executive's device. By definition, permeable cement is a blend of rock or rock stone, concrete, water, practically zero sand (fine total). At the point when permeable cement is utilized for clearing, the open cell structures permit storm water to channel through the asphalt and into the fundamental soils. As it were, permeable solid aides in securing the outside of the asphalt and its condition. As expressed above, permeable cement has indistinguishable essential constituents from ordinary solid, $15-30 \%$ of its volume comprises of interconnected void system, which permits water to go through the solid. Permeable cement can permit the section of 11.35-18.97 liters of water every moment through its open cells for each square foot $(0.0929 \mathrm{~m} 2)$ of surface region which is far more noteworthy than most downpour events. Aside from being utilized to kill or lessen the requirement for costly maintenance lakes, engineers and other privately owned businesses are likewise utilizing it to let loose important land for advancement, while as yet giving a cleared park. Permeable cement is likewise an interesting and viable intends to address significant ecological issues and supportable development. At the point when it downpours, permeable cement consequently goes about as a waste framework, in this manner returning water where it has a place. Permeable cement is harsh finished, and has a honeycombed surface, with a moderate measure of surface raveling which happens on intensely voyaged streets. The painstakingly controlled measure of water and cementations' materials are utilized to make a glue. The glue at that point frames a thick covering around total particles, to forestall the streaming off of the glue during blending and putting. Utilizing enough glue to cover the particles keep up an arrangement of interconnected voids which permit water and air to go through. The absence of sand in permeable solid outcomes in a brutal blend that adversely influences blending, conveyance, and situation. Additionally, because of the high void substance, permeable cement is light in weight (around 1600 to $2000 \mathrm{~kg} / \mathrm{m} 3$ ). Permeable cement can be utilized in a wide scope of utilizations, in spite of the fact that its essential use is in asphalts which are in private streets, rear entryways, and carports, low volume asphalts, low water intersections, walkways and pathways, stopping regions, tennis courts, incline adjustment, sub-base for regular solid asphalts, and so on.

1.2 ADVANTAGES
- Easy Installation
- Durable
- Low Costainable
- Can Be Temporary
- Can Be Used for Lawn Parking
- Eliminates Costly Drainage Systems
- Can be Used for Erosion Control
- Natural drainage reduces puddles
- Natural filtration
- Reod prevention
- Natural and sustainable materials




\subsection{Applications for Porous Concrete}

- Low-volume pavements

- Residential roads, alleys, and driveways

- Sidewalks and pathways

- Parking areas

- Low water crossings

- Tennis courts

- Sub-base for conventional concrete pavements

- Patios

- Artificial reefs

- Slope stabilization

- Well linings

- Tree grates in sidewalks

- Foundations/floors for greenhouses, fish hatcheries, aquatic amusement centers, and zoos

- Hydraulic structures

- Swimming pool decks

- Pavement edge drains

- Groins and seawalls

- Noise barriers

- Walls (including load-bearing)

\section{LITERATURE REVIEW}

Penetrable Concrete (PC) can decrease street upheaval, improve sprinkle and sprinkle, and improve granulating as a surface wearing course. A penetrable strong mix plan for a surface wearing course should meet the models of adequate quality and toughness under site-unequivocal stacking and regular conditions. As of recently, two key issues that have deterred the usage of Porous Concretein the United States are that characteristics of Porous Concretehave been lower than would regularly be suitable for required applications and the freeze-defrost strength of Porous Concretehas been suspect.

V.M. Malhotra (1976). Inspected Porous concrete as it relates to applications and properties. He gave nuances on such properties as consistency, degrees of materials, unit weight, similitude, and reestablishing attempting to intensify vulnerability in the Porous concrete. Malhotra furthermore coordinated various preliminaries on various test chambers attempting to find a connection between compressive quality and any of the material's properties. He induced that the compressive nature of Porous concrete was dependent upon the water solid extent and the all out solid extent.

Richard Meininger (1988). Released results on research focus investigations he had driven on Porous concrete. Examination was finished on various models with changing material properties. These properties included water solid extent, all out solid extent, compaction, and reestablishing time.

Nader Ghafoori (1995) wide exploration was driven by on various pieces of Porous concrete. In one assessment, he investigated various areas all through the United States that have utilized Porous strong clearing systems. His assessment incited a connection of compressive quality achieved at all of these districts. He furthermore investigated disillusionments in the various pavements if any had occurred close by the water concrete and absolute solid extents.
Ghafoori (1995), researched usages of Porous concrete outside the United States and eventually took a gander at the compressive characteristics. He is similarly looks at, in detail, black-top thickness plan for Porous concrete. He finds that compressive quality depends upon the water solid extent, the complete solid extent, compaction, and calming. He similarly gives a blueprint which shows the effects of fluctuating the all out solid extent and compaction imperativeness have on the compressive quality and permeability.

Paul Klieger (2003) performed tests thinking about the effects of entrained air on the quality and robustness of customary concrete. But never utilizing the proportion of voids seen in Porous concrete (15\%-35\%), his investigation evidently shows the impact the closeness of air has on the introduction of concrete. He construed that the abatement in compressive quality with the proximity of air reduces as the size of complete decays and as the solid substance decreases. These are both in light of the abatement in water.

Yang and Jing (2003). It ensured the reduction of all out size provoked higher Porous strong quality, coming about on account of the development of the interface quality between the aggregate and solid paste. Using the ordinary material and method, the nature of the Porous concrete is low. However, using smaller aggregate, silica smoke and super plasticizer in the past strong quality can be extended altogether. Furthermore by growing the solid paste latch district and updating the nature of solid folio Porous strong quality can in like manner be extended. The Porous blacktop materials that made out of a surface layer and a base layer were made.

Tennis Paul et. Al I (2004). Examined the copied simples of Porous concrete surrounded from two stone hotspots for coarse aggregates and particular size parts to choose hydrologic associations. Straight associations were found among thickness and porosity, thickness and permeability, porosity and vulnerability, porosity and unequivocal yield. The results suggest that properties, for instance, permeability, porosity and unequivocal yield are not in a general sense impacted by different absolute sorts.

\section{III.EXPERIMENTAL MATERIALS:}

Permeable Concrete is a blend of Cement, Coarse Aggregate practically no sand and Water. Fine Aggregates are not utilized for making Porous properties in concrete. Now and again admixtures are utilized for accomplishing additional quality and unique properties of Porous cement.

\subsection{CEMENT:}

Concrete is a key to system industry and is used for various purposes and moreover made in various structures. Improvement of amazingly high compressive quality in starting periods helps in early covering. Intense Concrete Feasible for commonsense strong mix structures. 


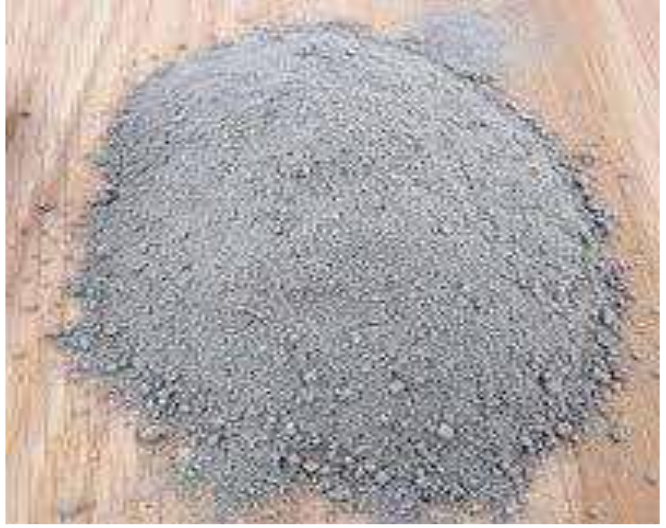

Figure3.1: Ordinary Portland cement

Table 1: - Properties of Cement

\begin{tabular}{|l|c|c|}
\hline \multicolumn{1}{|c|}{ Property } & $\begin{array}{c}\text { Values of Cement } \\
\text { (PPC) }\end{array}$ & $\begin{array}{c}\text { AS per IS: } \\
\mathbf{1 2 2 6 9 - 1 9 8 7}\end{array}$ \\
\hline Specific Gravity & 2.93 & $3.10-3.15$ \\
\hline Consistency (\%) & $31.5 \%$ & $30-35(\%)$ \\
\hline Initial setting time (Min) & 34 minutes & 30 minutes \\
\hline Final setting time (Min) & 240 minutes & 600 minutes \\
\hline $\begin{array}{l}\text { Compressive strength at } 7 \\
\text { days (N/mm²) }\end{array}$ & $39.50 \mathrm{~N} / \mathrm{mm}^{2}$ & $43 \mathrm{~N} / \mathrm{mm}^{2}$ \\
\hline $\begin{array}{l}\text { Compressive strength at } 28 \\
\text { days (N/mm2) }\end{array}$ & $51 \mathrm{~N} / \mathrm{mm}^{2}$ & $53 \mathrm{~N} / \mathrm{mm}^{2}$ \\
\hline
\end{tabular}

\subsection{AGGREGATES}

Coarse Aggregates is the section of the strong which is included the greater stones embedded in the mix. Concrete contains three fixings; Water, cement, and aggregate. particle shape and size, surface, and digestion. The standard kind total for use in pervious cement is commonly squashed stone or waterway rock. Run of the mill sizes are from $10 \mathrm{~mm}$ t $25 \mathrm{~mm}$.

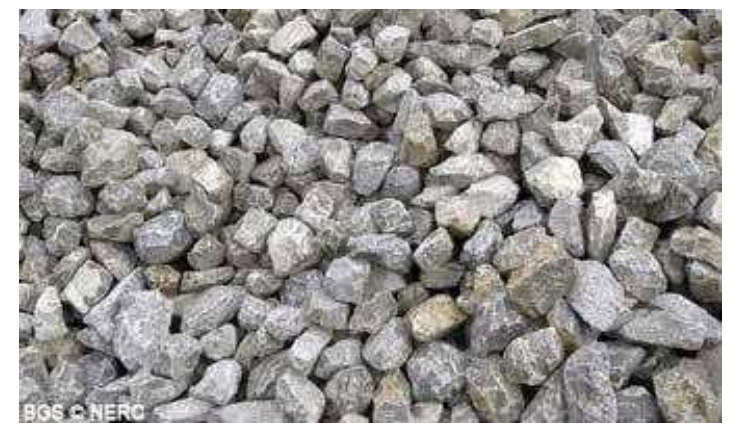

Figure 3.2: Coarse Aggregates

Table 2: - Properties of Coarse Aggregates

\begin{tabular}{|c|l|c|}
\hline S.No & \multicolumn{1}{|c|}{ Particulars } & Values \\
\hline 1 & Density $\left(\mathrm{Kg} / \mathrm{m}^{3}\right)$ & 1830 \\
\hline 2 & Fineness Modulus & 7.53 \\
\hline 3 & Specific Gravity & 2.78 \\
\hline 4 & Water absorptions (\%) & 1.60 \\
\hline 5 & Surface moisture & Nil \\
\hline
\end{tabular}

\subsection{WATER}

While any consumable water can be used for mixing, the proportion of water is fundamental for the improvement of the voids in pervious concrete. Water-to-cement extents can run from 0.27 to 0.30 with extents as high as 0.40 . Wary control of water is fundamental.
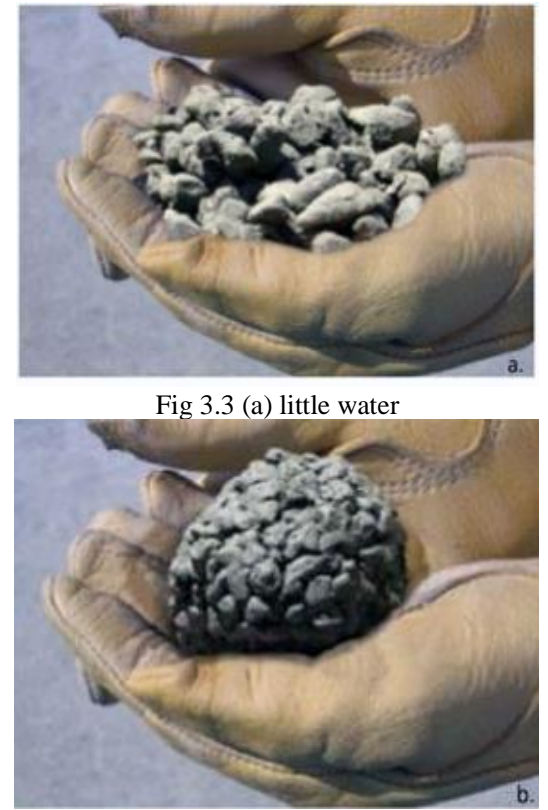

Fig 3.3 (b). Correct amount of water

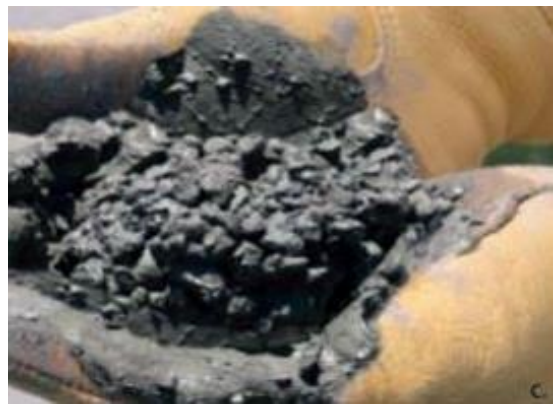

Figure 3.3. (c) Much water.

\subsection{METAKAOLIN}

Metakaolin is an admixture utilized as an incomplete substitution of concrete. A solid is expressed to be over the top power concrete if its compressive quality is more than 40Mpa. Metakaolin is prepared by method for calcination of kaolin (clay mineral) at a temperature of $650-800^{\circ} \mathrm{C}$.It has pozzolanic homes. It responds with $\mathrm{Ca}(\mathrm{OH}) 2$ one of the through-results of hydration reaction of concrete and impacts in extra C-S-H gel which prompts expanded quality.

\subsubsection{DESIGN}

- Grade designation:M40

- Maximum nominal aggregate size : $20 \mathrm{~mm}$

- Minimum cement content : $320 \mathrm{~kg} / \mathrm{m} 3$

- Maximum water cement ratio : 0.38

- Workability : 100mm (Slump)

- Exposure condition : Severe

- Degree of supervision : Good

- Type of aggregate : Crushed angular aggregate

- Maximum cement content (OPC) : $400 \mathrm{~kg} / \mathrm{m} 3$

- Chemical admixture type : Super plasticizer confirming to IS-9103 


\subsubsection{MATERIALS REQUIRED FOR M40 GRADE OF CONCRETE}

\begin{tabular}{|l|l|}
\hline Cement & $466.66 \mathrm{~kg}$ \\
\hline Coarse aggregate & $1140 \mathrm{~kg}$ \\
\hline Admixture & $7 \mathrm{~kg}$ \\
\hline Water & 140 litres \\
\hline
\end{tabular}

\subsubsection{PROPORTIONS}

\begin{tabular}{|c|c|c|c|}
\hline MIXES & CEMENT & METAKOLIN & C.A \\
\hline Mix-1 & 1.00 & 0 & 2.44 \\
\hline Mix-2 & 0.95 & 0.05 & 2.44 \\
\hline Mix-3 & 0.90 & 0.10 & 2.44 \\
\hline Mix-4 & 0.85 & 0.15 & 2.44 \\
\hline Mix-5 & 0.80 & 0.20 & 2.44 \\
\hline
\end{tabular}

\section{RESULTS AND DISCUSSION}

\subsection{COMPRESSIVE TEST}

Compressive strength is dependent on size of coarse aggregate, void ratio, bond between mortar and coarse aggregate.

\subsection{SPLIT TENSILE STRENGTH}

In this project we conducted the split tensile test for cylinder. In pervious concrete tensile strength vary from 1 to $3.5 \mathrm{Mpa}$.

\subsection{TEST RESULTS}

\section{COMPRESSIVE STRENGTH}

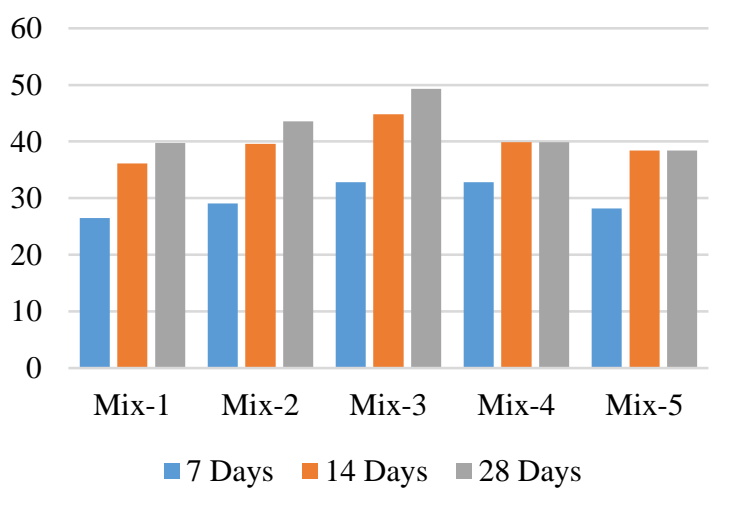

\subsubsection{SPILT TENSILE STRENGTH}

\section{SPILT TENSILE STRENGTH}

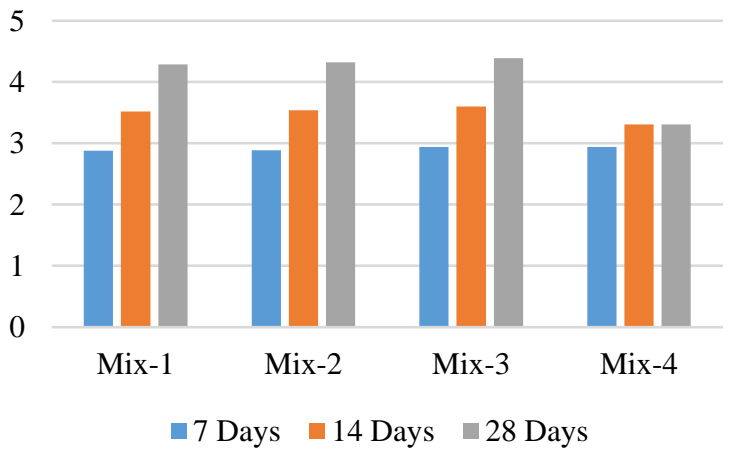

\section{CONCLUSION}

In view of test examination, following perceptions are made on the new and solidified properties of Pervious cement.

- Pervious concrete have less compressive quality contrasted with traditional cement.

- Permeability is high because of high void substance.

- The utilization of pervious cement ought to be constrained to zones not exposed to high volumes of traffic.

- Even however the compressive quality of the pervious cement is extensively not as much as that of customary cement. The entirety of the blends tried, be that as it may, didn't accomplish compressive quality sufficiently able to continue such high vehicle loadings.

- Suggestions are that pervious concrete be compelled to regions that are presented to little vehicle loads with intermittent use by greater vehicles. Pervious concrete, in spite of the fact that not as solid as customary cement, gives a worthy elective when utilized in low volume and low effect regions.

- Strength is relinquished for penetrability however not to any degree which would deliver the pervious cement non-practical.

\section{REFERENCES}

[1] V.M.Malhotra "No-Fines Concrete - Its Properties and Applications", ACI Journal, November 1976, Vol. 73, Issue 11, pp 628-644.

[2] Klieger, Paul "Further Studies on the Effect of Entrained Air on Strength and Durability of Concrete with Various Sizes of Aggregate”, Concrete International, November 2003, Vol. 25, No. 11, pp 26-45.

[3] Ghafoori, Nader, "Pavement Thickness Design for No-Fines Concrete Parking Lots”, Journal of Transportation Engineering, November/December 1995, Vol. 121, No. 6, pp 476-484.

[4] Chopra M. , Wanielista, (2007): "Performance assessment of Portland cement pervious concrete”, Rep. Prepared for Storm water Management Academy, Univ.of Central Florida, Orlando, Fla, pp. 1125.

[5] Mr.V. R. Patil Prof. A. K. Gupta "Use Of Pervious Concrete In Construction Of Pavement For Improving Their Performance" (2006) VOL. 2 PP: 54-56.

[6] Meininger, Richard C., "No-Fines Pervious Concrete for Paving", Concrete International, August 1988, Vol. 10, No. 8, pp 20-27.

[7] Harber, P.J. (2005): "Application of No-fines concrete as a Road Pavement”, Rep. Univ., of Southern Queensland, pp. 1-130.

[8] Brown, Dan, "Pervious Concrete Pavement: A Win-Win System", Concrete Technology Today, August 2003, Vol. 24, No. 2, pp 1-3.

[9] Chopra, M.M., Kakuturu, S., Ballock, C., Spence, S. and Wanielista, M.M. (2010): "Effect of rejuvenation methods on the infiltration rates of pervious concrete pavements", J. ASCE, 15(6).

[10] A.M Made and S.Rogg (2013), “ Development of High Quality Pervious concrete Specification For Maryland Conditions" Final Report MD-13-SP009B4F.

[11] Kevern, J.1 , Wang, K. "Pervious concrete pavement has been in use for over 30 years in Florida and an experimental road" was constructed in England in the 1960's (Youngs 2005, Maynard 1970).

[12] IS 5816-1976 Code of practice for "SPLIT TENSILE STRENGTH TEST".

[13] IS: 516-1959 Code of practice for "COMPRESSIVE STRENGTH TEST". 